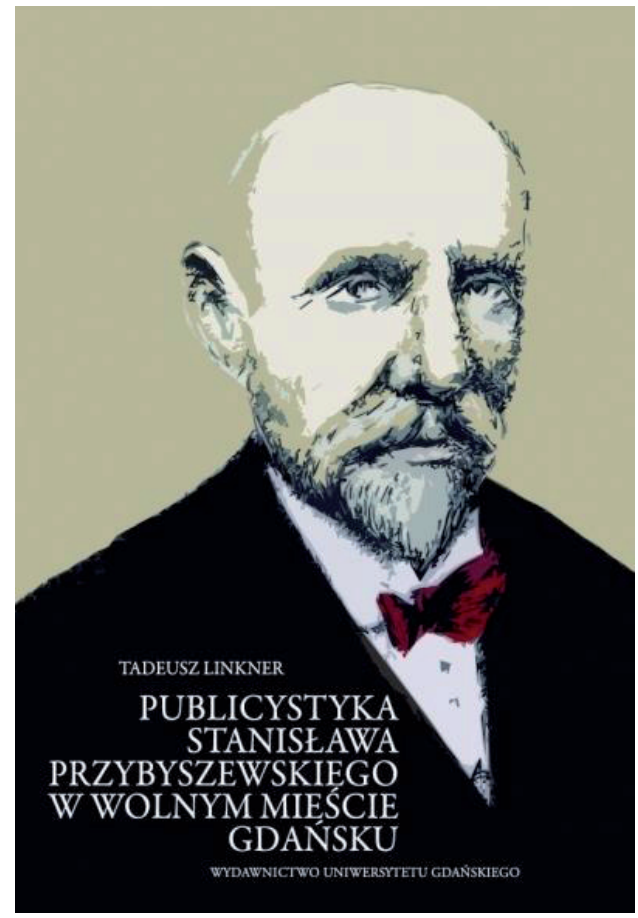

Hanna Ratuszna

\section{Przybyszewski w Wolnym Mieście Gdańsku}

DOI: http://dx.doi.org/10.12775/LC.2016.066

szkicu Stanistaw Przybyszewski.

Legenda i rzeczywistość Artur Hutnikiewicz pisał:

Nie ma tu co ukrywać, trzeba przyznać się otwarcie, że nie tylko dla statystycznego inteligentnego Polaka, ale i dla historyka literatury Przybyszewski jest osobistością wciąż właściwie nieznaną i nieomal mityczną. Fenomen autora De profundis jest przykładem wyjątkowej, na ogół niezwykle rzadko spotykanej mistyfikacji, rzadko ze względu na zasięg i totalność, bo ogarnia ona wszystko, zarówno życie, jak i dzieło. O Przybyszewskim nic się naprawdę nie wie $^{1}$.

Słowa wypowiedzianew 1968 r. nie straciły swej aktualności, mimo wielu nowych prac poświęconych Przybyszewskiemu, autorstwa Jacka Kolbuszewskiego, Gabrieli Matuszek, Wojciecha Gutowskiego, Tadeusza Linknera, Anny CzabanowskiejWróbel, Pawła Dybla, Adama Jarosza i innych ${ }^{2}$, wciąż nie udało się zebrać i opracować krytycznie wszystkich dzieł autora $D e$ profundis i wyjaśnić zagadek jego biografii.

Stanisław Przybyszewski jest artystą, którego twórczość wciąż inspiruje pokolenia badaczy. Sytuacja ta nie budzi zdziwienia, autor Śniegu był nie tylko pisarzem, dramaturgiem, lecz przede wszystkim animatorem kultury w XIX-wiecznym Krakowie. Z miastem tym najczęściej związane są wspomnienia, modernistyczne peregrynacje badaczy. Opublikowana w 2015 r. książka Tadeusza Linknera Publicystyka Stanisława Przybyszewskiego $w$ Wolnym Mieście Gdańsku wzbogaca wiedzę na temat tego aspektu działalności Przybyszewskiego, ukazuje znaczącą rolę Gdańska w twórczości i rozwoju duchowym autora, prezentuje go jako obrońcę polskości, społecznika, artystę, który - wbrew sądom - nie zastygł w modernistycznej pozie, choć niewiele brakowało, by tak właśnie się stało.
1 A. Hutnikiewicz, Stanistaw Przybyszewski. Legenda i rzeczywistość, w: idem, Portrety i szkice literackie, WarszawaPoznań-Toruń 1976, s. 41.

2 Wśród najważniejszych prac warto wymienić najnowsze: G. Matuszek, Stanistaw Przybyszewski - pisarz nowoczesny. Eseje i proza - próba monografii, Kraków 2008; Przybyszewski - rewizje i filiacje, pod red. G. Matuszek, Kraków 2015; W. Gutowski, Konstelacje Przybyszewskiego, Torun 2008; P. Dybel, Urwane ścieżki. Przybyszewski-FreudLacan, Kraków 2000; K. Badowska, „Godzina cudu”. Mitość i erotyzm w twórczości Stanistawa Przybyszewskiego, Łódź 2011. 
Przybyszewski odwiedził Gdańsk w szczególnym momencie życiowej drogi w 1920 r., gdy skończył się jej etap krakowski. Warto przypomnieć kilka faktów, które pozwolą zrozumieć, w jak trudnej sytuacji znalazł się pisarz. Po tragicznej śmierci Dagny w Tyflisie, gdy zakończyła się ostatecznie współpraca z redakcją „Życia”, po skandalu związanym z romansem z żoną przyjaciela, Jadwigą Kasprowiczową, Przybyszewski nie mógł już zostać w Krakowie. Miasto, które przyjęło go jako wyczekiwanego proroka nowej sztuki w 1899 r., widziało w nim teraz jedynie „proroka wykolejeńców”. Miał Przybyszewski zaufanych przyjaciół (takich jak np. „Stasinek” Sierosławski czy Tadeusz Boy-Żeleński), jednak zła sytuacja materialna zmuszała go do poszukiwania nowego miejsca. Kraków, zmęczony skandalami, witał wówczas innego mistrza - Stanisława Wyspiańskiego.

Relacje artystów z tego okresu, opisane przez wielu badaczy, m.in. Marię Podrazę- Kwiatkowską ${ }^{3}$, wciąż budzą emocje. Przybyszewski spotkał Wyspiańskiego w redakcji „Życia”. Przyszły autor Wesela dbał o szatę graficzną pisma, które było przeznaczone „wyłącznie dla artystów”, promowało sztukę i literaturę europejskiej moderny. Współpraca nie trwała zbyt długo, w tym czasie zdążył jednak Wyspiański sportretować samego Przybyszewskiego, jego syna Zenona i dwukrotnie „Panią Dagny”. Przybyszewski zaś wpisał mu piękną dedykację do tomu Nad morzem, który ilustrował jeden z portretów Dagny. Prace Wyspiańskiego, portreciki artystów, związanych głównie z kręgiem Przybyszewskiego, zdobiły ścianę Paonu, wkrótce jednak i one zniknęły (malarz zażądał zwrotu swoich

\footnotetext{
3 M. Podraza-Kwiatkowska, Z rekwizytorni Stanisława Wyspiańskiego: latające, goniące, chodzące trumny i ich związek z Przybyszewskim, w: eadem, Labirynty - kładki - drogowskazy. Szkice o literaturze od Wyspiańskiego do Gombrowicza, Kraków 2011, s. 107-124.
}

prac, zrywając tym samym relacje $\mathrm{z}$ krakowską cyganerią. Warto podkreślić, że on sam nigdy nie czuł się cyganem). Zdarzenie to pokazuje wyraźnie, jak artysta funkcjonował w środowisku krakowskim: w przeciwieństwie do Przybyszewskiego nie potrzebował otaczać się „świtą”. Partnerami w dyskusjach o sztuce byli dla niego wieloletni przyjaciele, tacy jak np. Lucjan Rydel (por. listy do Lucjana Rydla). Cyganeria i kawiarniany styl nigdy nie budzily fascynacji Wyspiańskiego, który pozostał „artystą osobnym”.

Przybyszewski przeżywał sukces Wesela już poza Krakowem. Poszukując nowego miejsca zamieszkania w Warszawie czy w Toruniu, autor Śniegu wracał wspomnieniami do czasów dawnej świetności. W listach pisanych z Torunia w 1906 r. pobrzmiewają wyraźnie echa zawodu, związanego z tym, że Kraków nie pamięta o nim (por. list z 2 stycznia 1906 r.) $)^{4}$. W Moich wspótczesnych, pamiętniku spisywanym u schyłku życia, Przybyszewski odrzucił jednak złe wspomnienia, Wyspiański był dla niego mistrzem, spotkania w 1899 r. nabrały innego wymiaru, okazały się cenne, owiane urokiem utopijnego hasła „sztuka dla sztuki”.

Książka Tadeusza Linknera pt. Publicystyka Stanistawa Przybyszewskiego $w$ Wolnym Mieście Gdańsku oświetla okres tułaczki w poszukiwaniu nowych miejsc („miejsc ocalenia”), wydobywa niezwykłe emocje uwikłane w słowa i gesty sprzed wielu lat. Przybyszewski powraca w niej jako artysta, który przebył daleką drogę. Tułaczka warszawska, szczególnie zaś monachijska, wpłynęły na postawę artysty, niegdyś niepokornego, który pozbawiony poklasku tłumów, w zapomnieniu, próbuje odnaleźć się

\footnotetext{
4 St. Przybyszewski, List do żony Jadwigi (Toruń, 2.01.1906), w: idem, Listy, t. 1, oprac. St. Helsztyński, Warszawa 1937, s. 338.
} 
w nowej, powojennej rzeczywistości, łączy pracę zawodową $\mathrm{z}$ artystyczną.

Gdańsk widziany z tej perspektywy jest miejscem szczególnym. Jego niezwykły portret stanowi interesujące tło dla rozważań o sztuce, polskości i ciąglych poszukiwaniach artysty. W Gdańsku, jak pisał Przybyszewski: „można spokojnie żyć i pracować”.

2.

Przyjazd do Wolnego Miasta nastąpił wlipcu 1920 r., Przybyszewski opuściłzasobny Poznań, w którym jednak nie mógł dłużej pozostać. Praca w urzędzie pocztowym (w Dyrekcji Poczt i Telegrafów) nie przyniosła finansowych satysfakcji, ciągłe kłopoty mieszkaniowe zmusiły Przybyszewskich do wyjazdu. Jak interesująco komentuje ten wątek Tadeusz Linkner, Gdańsk okazał się dla pisarza koniecznością. Objęta przez niego posada pisarza w Dyrekcji Polskich Kolei Państwowych stwarzała możliwość działalności artystycznej, przede wszystkim jednak wyzwoliła w nim ducha polemiki, publicystycznej debaty. Przybyszewski powrócił w Gdańsku do pracy, którą rozpoczął w Berlinie, gdzie zajmował się redagowaniem „Gazety Robotniczej”. Jakkolwiek czasy berlińskie nie były przez niego dobrze wspominane (współpraca $\mathrm{z}$ redakcją zakończyła się skandalem i aresztowaniami), to sytuacja polityczna i warunki społeczne w Wolnym Mieście, w którym umacniała się polskość, okazały się niezwykle sprzyjające dla działalności publicystycznej.

W Gdańsku rozwijały się wówczas polskie organizacje, Przybyszewski zaś rozumiał potrzeby chwili, doskonale orientował się w sytuacji politycznej. Jego wypowiedzi prasowe charakteryzuje erudycja, słowna wirtuozeria i niezwykła intuicja, którą autor książki, Tadeusz Linkner, ceni najbardziej. W jego komentarzach pojawiają się współ- czesne konteksty, pobrzmiewają echa słów Przybyszewskiego, uwagi na temat popleczników Polski, tych rzeczywistych oraz tych, którzy próbowali wyzyskać trudną sytuację odradzającego się narodu:

Przybyszewski rozumial, że niekorzystny dla Niemiec efekt plebiscytu nie służył również interesom Anglii, stąd starała się ona na wszelkie możliwe sposoby temu zapobiec, nie sprzeciwiając się nawet „haniebnemu manewrowi” z owymi dwustu tysiącami głosów na rzecz przynależności Śląska do Niemiec. Wiadomo, że był to typowy „angielski kant”, jak zwał to Przybyszewski, ponieważ niemieccy przybysze biorący udział $\mathrm{w}$ tym plebiscycie to w cudzysłowie „mający tyle styczności ze Śląskiem, co my z Księżycem”. Przy czym pozwoliło to Przybyszewskiemu przypomnieć raz jeszcze Irlandię, co zarazem tłumaczyło antypolską reakcję angielskiego polityka wobec walczącego $\mathrm{w}$ sprawie przypisania Polsce Śląska. Otóż zaistniała obawa, że „bohaterskim szlakiem Śląska podąży Irlandia!”. Tak więc w mniemaniu Przybyszewskiego głównie przestrach przed Irlandią, która mogłaby obudzić się do czynu, nakazał Lloydowi George’owi tak kłamać. Nie mówiąc już o niedocenianiu przez ententę pokonania bolszewików nad Wisłą, co tylko „potworne kłamstwo” Lloyda George’a wspomagało. Wszak nikomu nie powinniśmy za „cud nad Wistą” dziękować, a Anglii najmniej5.

Gdańsk odzyskiwał swoje siły i właśnie wtedy Przybyszewski odegrał bardzo ważną rolę. Pisarz w czasie obchodów trzydziestolecia pracy twórczej zbierał datki na Gimnazjum Polskie, był jednym z pomysłodawców i najważniejszym realizatorem tej idei, podejmował kwesty we Lwowie, w Krakowie, Warszawie, Bydgoszczy, Łodzi, nawet w Tarnowie. Uzyskał także wsparcie

\footnotetext{
5 T. Linkner, Publicystyka Stanistawa Przybyszewskiego w Wolnym Mieście Gdańsku, Gdańsk 2015, s. 90.
} 
od dawnych berlińskich i monachijskich przyjaciól. Ogromna akcja, która objęła ludzi popierających działalność Macierzy Szkolnej, nie miałaby tak wielkiego powodzenia bez orędownika sprawy polskiej, który w wystąpieniach na łamach „Dziennika Gdańskiego” i później „Gazety Gdańskiej” nieustannie przypominał o konieczności odbudowy „potencjału intelektualnego” tych ziem, wskazywał na korzyści płynące z rozwoju oświaty w Wolnym Mieście.

Interesująca, ważna $\mathrm{z}$ historycznego punktu widzenia okazuje się uwaga Linknera, dotycząca wcześniejszego politycznego i społecznego zaangażowania Przybyszewskiego. W czasie pobytu w Poznaniu Przybyszewski opublikował „broszurę” Poznań Ostoja myśli naszej. Epizod ten, jak wyjaśnia autor książki, miał istotne znaczenie. Poznańscy działacze społeczni nie ocenili należycie starań pisarza, który widział w tym mieście przyszłą stolicę Wielkopolski, ważne centrum kulturalne, oświatowe. Doświadczenia poznańskie predestynowały pisarza do odważnych, niezwykle przemyślanych wystąpień w gdańskiej prasie, które nie mogły umknąć uwadze niemieckich władz (Przybyszewski nie był wówczas mile widziany w Niemczech). Zasługi, jakie miał w rozwoju literatury niemieckiej, ani jego sława jako artysty nie stanowily ochrony przed antypolską działalnością Niemiec.

Interesująca, $\mathrm{z}$ punktu widzenia badawczego, okazuje się także kolejna uwaga Linknera, dotycząca działalności publicystycznej pisarza: otóż nie wszystkie artykuły Przybyszewski podpisywał własnym nazwiskiem, niektóre z nich, ewidentnie jego autorstwa, są sygnowane inicjałami brata, Leona, który pracował wówczas w redakcji „Gazety Gdańskiej”. Być może również (ta hipoteza pobudza wyobraźnię najbardziej) Przybyszewski pisał pod pseudonimem do prasy niemieckiej. Jak jednak słusznie zauważa autor imponującego szkicu poprzedzającego bogaty aneks, pozwalający zweryfikować przedstawione tezy i zapoznać się z działalnością Przybyszewskiego w Gdańsku, wągrowiecki artysta nie cenił niemieckiej prasy, pisane przez niego artykuły były przeznaczone wyłącznie dla polskich czytelników.

Dwudzielna kompozycja książki Linknera, zawierająca obszerny szkic oraz aneks z artykułami, stanowi dla czytelników miłą niespodziankę. Wnikliwie omówione $\mathrm{w}$ inicjującym tom szkicu artykuły, odnalezione w aneksie - umożliwiają weryfikację przeczytanych wcześniej tez. Przywołany w ten sposób „głos Przybyszewskiego” uwierzytelnia wcześniejsze wywody, stanowi dokument minionej, jakże jednak ważnej w historii rozwoju polskiej myśli epoki.

\section{3.}

Przybyszewski zainicjował swoją działalność publicystyczną w Gdańsku historyczno-politycznym artykułem Stanisław Przybyszewski powstańcom 29 listopada 1830, poświęconym rocznicy powstania listopadowego. Obchody uroczystości zostały zorganizowane przez pracowników kolejowej dyrekcji w Strzelnicy w Gdańsku. Odczyt Przybyszewskiego wygłoszony 10 grudnia 1920 r. (opublikowany pięć dni później w „Dzienniku Gdańskim”) spotkał się ze szczerym uznaniem, autor odwoływał się w nim do tradycji polskich ziem, mówił o sponiewieranej „Duszy Polski”, o narodowym posłannictwie i o właściwym rozumieniu słowa „wolność”. Artykuł był więc głosem o współczesności, osadzonym w tradycji historycznej. W wypowiedzi nie zabrakło młodopolskiej metaforyki światła: jutrzenki, bladego świtu oraz mroków nocy. Pisarz słusznie uważal, że obecna wolność jest konsekwencją polskich zrywów niepodległościowych i że „w prostej linii” 
zawdzięczać ją trzeba bohaterskim wydarzeniom z 1830 r.: „współczesna Europa nie może istnieć bez Polski”. Istnieje jednak inne oblicze wolności, o którym - jak pisał Linkner - nie można zapomnieć:

Ten krótki czas wolności pozwolił wypełznąc na wierzch podłemu robactwu: tchórzom o złodziejskim sprycie, podłemu plemieniu, które po krwawych godach ciałem poległych wojów się żywi, z bohaterskich skroni zrywa wawrzyny i plugawy handel nimi prowadzi - ten czas, który miał być jednym wielkim zbożnym świętem, pozwolił się rozpanoszyć podłej bestii w człowieku, która swą brudną, tłuszczem ociekającą łapą dławi najszlachetniejsze porywy duszy polskiej, zniechluja i zabagnia najczystsze źródła istotnej duszy całego narodu ${ }^{7}$.

Wystąpienie Przybyszewskiego zainicjowało cykl artykułów, w których historyczny rys wydarzeń był uzupełniany refleksjami o współczesności. Autor Śniegu pisał m.in. o Józefie Piłsudskim ( $w$ dniu jego imienin - 19 marca 1921 r.), którego czyn porównywał do działań Mickiewicza, parafrazował słowa Konrada z Improwizacji z III części Dziadów, akcentując rzeczywiste postawy. Działalność Legionów określał jako „czwarte powstanie Polski”. Przybyszewski wypowiadał się także na temat spraw bieżących, np. o podpisanym 18 marca $1921 \mathrm{r}$. traktacie w Rydze (por. artykuł z 20 marca 1921 r.). Linkner, oceniając tę wypowiedź, zwrócił uwagę na przenikliwość sądów jej autora:

Pokój ryski co prawda dał nam nadzieję „szczęśliwej i jaśniejszej przyszłości”, ale nie należało go witać ze zbytnim entuzjazmem. Przybyszewski miał oczywiście ra-

\footnotetext{
6 Cyt. za: T. Linkner, op. cit., s. 66.

7 St. Przybyszewski, Powstańcom 29 listopada 1830, w: T. Linkner, op. cit., s. 216.
}

cję, jeżeli przyszłość dość rychło pokazała, jak jego obawy się ziściły ${ }^{8}$.

Przybyszewski podejmował także temat Kaszubów, których polskość cenil, oraz pisał w obronie Śląska. Wszystkie wystąpienia prasowe służyły sprawie polskiej, pisarz zastanawiał się $\mathrm{w}$ nich nad przyszłością Polski, która, choć obdarzona wolnością, ciągle jeszcze „leczyła rany”. Warto zwrócić uwagę na niebagatelny trud poniesiony przez Tadeusza Linknera, który w szkicu wstępnym zadbał nie tylko o spójne, rzeczowe informacje historyczne (rekonstrukcję wydarzeń, analizy i diagnozy), lecz także przedstawił czytelnikowi bogactwo biograficznych szczegółów związanych $\mathrm{z}$ osobą Przybyszewskiego. Zarysowany w ten sposób plan zdarzeń wypełnił barwną narracją o działalności Arcycygana, Koryfeusza Młodej Polski, który uświetnił Gdańsk, dostrzegając w nim ważny, strategiczny dla Polski ośrodek oraz „źródło polskości”. Nie dziwi zatem kolejna decyzja pisarza, by właśnie tu, na Pomorzu, powstał Dom Polski, wzorowany na gandawskim „Ons Huys”. Przybyszewski, podobnie jak w przypadku Gimnazjum Polskiego, próbował zbierać fundusze na ten cel, czuł wielką odpowiedzialność za to przedsięwzięcie.

Historia Domu Polskiego, podobnie jak losy Gimnazjum, nie napawają jednak optymizmem. Linkner z żalem pisze, że zabrakło Przybyszewskiego na uroczystościach otwarcia Domu Polskiego, w którym po śmierci pisarza doszło do sporów i waśni związanych ze sprawowaniem władzy, nikt także nie wspominał o jego zasługach. Przybyszewski przygotowując otwarcie Gimnazjum Polskiego, zapraszał gości na „gody”, traktował to wydarzenie jak wielkie, rodzinne święto, o którym również dość szybko zapomnieli potomni. Jak można jed-

\footnotetext{
8 T. Linkner, op. cit., s. 83
} 
nak sądzić, nie pamięć jest w tym przypadku najważniejsza (choć przeczy temu książka Linknera), lecz dzieło, które pozostawił po sobie pisarz.

Przybyszewski okazał się znakomitym organizatorem, orędownikiem oświaty, animatorem kultury. Dzięki jego staraniom rozwinęła działalność biblioteka kolejowa, dla której pozyskał 1000 woluminów z Lwowa, podobnie starał się o książki dla biblioteki gimnazjalnej, prosząc swoich przyjaciół o darowizny (np. Boya-Żeleńskiego). Jako pierwszy wpisał się do księgi pamiątkowej gimnazjum. Wpis ten budzi wiele emocji, ujawnia bowiem intencje artysty, który „nie dla próżnej chwały, nie dla próżnej sławy" podjął organizacyjny trud.

Wielką zaletą książki o publicystyce Przybyszewskiego jest nie tylko rzetelna analiza danych, systematyzacja artykułów rozrzuconych po numerach „Dziennika Gdańskiego” i „Gazety Gdańskiej”, które na krótko wychodzily nawet pod wspólnym szyldem, lecz przede wszystkim obecność solidnego komentarza historycznoliterackiego, który pozwala właściwie sytuować fakty, interpretować je, dostrzec grę sił politycznych, dylematy narodowościowe społeczności Wolnego Miasta Gdańska. Przybyszewski cenił niemieckie przyjaźnie, wspaniale wyrażał się o sztuce, literaturze, kulturze niemieckiej, nie mógł jednak zrozumieć, dlaczego otrzymał zakaz pobytu w Niemczech. Dlaczego stał się persona non grata. Nie przeciwstawiał się jednak zakazom.

Tadeusz Linkner prezentuje w swojej książce sylwetkę artysty, który na moment zatrzymał się w Gdańsku, tu jednak, w czasie czteroletniego pobytu, zrozumiał swoją rolę w wolnej Polsce, szukał jej pełnej realizacji. Przybyszewski nie mógł się przyzwyczaić do bliskości morza. Jak wynika z listów cytowanych przez autora, traktował je jak żywy organizm, z którym należy się zaprzyjaźnić lub zerwać wszelkie kontakty.
Uwaga ta jest dość ciekawa - w twórczości pisarza morze zawsze odgrywało wielka rolę, podobnie jak gotyk, było motywem przewodnim. W Moich wspótczesnych potęga gotyku, ekspresja sztuki została porównana do morskiego żywiołu. Pisarz powrócił do morskiego, bałtyckiego motywu także w ostatnim swoim dramacie Mściciel z 1927 r. Przedstawiony przez niego nadmorski pejzaż przywodzi na myśl urwisko w Orłowie, które artysta znał, wspominał o tym miejscu w listach. Wspomnienie morza połączyło zatem wczesną twórczość z tą, która powstała u schyłku artystycznej drogi. Poemat Nad morzem ukończony w Playa del Mar (w 1899 r.) niósł słowiańskie przesłanie, subtelne wspomnienie Bałtyku, który pisarz poznał jeszcze jako dziecko. Żywioł wody, symbolika i wierzenia związane z Gopłem towarzyszyły mu od samego początku.

Przybyszewski pisał $\mathrm{w}$ opowiadaniu Nad Goptem:

Rowy się do was uśmiechną krwawnikami, a zboże odsłoni w sobie tu modrak, tam mak. I przyjdą dziewanny z piasków, a łopiany was oblegną zewsząd, zaś mokradła będą z daleka, jak zwykle bełkotać żabimi głosami. A potem „ono” zabłyśnie w ramie wiecznej z sitowi i trzcin: Gopło. I zacznie się po swojemu ważyć i chwiać. A później lękliwie zakwilą kuliki i odezwie się pobrzęk topól i muzyczne mruczenie chrząszczy, nigdy niezmienna melodia Nadgopla9

Nad Gopłem, w Jarontach pisarz zakończył życie.

9 St. Przybyszewski, Nad Goptem, w: J. Balicki, S. Maykowski, Będziem Polakami, Lwów-Warszawa-Kraków 1928, s. 46. 
Książka Tadeusza Linknera pozwala poznać inny wymiar twórczości artysty, którego Niemcy nazywali der geniale Pole. Jego życie postrzegane przez pryzmat licznych skandali i konwersji nabrało w Gdańsku innego wymiaru. Artysta doskonalił w Wolnym Mieście naukę języka hebrajskiego, wrócił do studiów nad kabałą, pracował nad odczytami o czarnej magii, nad studium o czarnoksięstwie (jednym $\mathrm{z}$ rezultatów podjętych prac była powieść Il regno doloroso), nie zaniedbywał jednak obowiązków na kolei, gdzie pracowal jako tłumacz, autor słownika technicznego związanego z kolejnictwem, przygotowywał wyciągi prasowe o kolei, był bibliotekarzem. Cicha urzędnicza praca, dająca poczucie stabilizacji, lecz także niekiedy monotonii, mobilizowała do większego zaangażowania się $\mathrm{w}$ sprawy społeczne Gdańska. Jak kończy swoją opowieść Linkner, Gdańsk nie zatrzymał Przybyszewskiego, choć nie było to ostatnie spotkanie z Wybrzeżem, pisarz powracal tu jeszcze dwukrotnie, nigdy jednak na tak długo, nigdy z zamiarem pozostania na stałe.

Interesujący szkic o publicystyce Przybyszewskiego kończy refleksja poświęcona czytelniczym peregrynacjom autora Śniegu. Linkner przypomina sylwetkę niemieckiego pisarza Hannsa Heinza Ewersa, autora powieści Alraune, Uczeń czarnoksiężnika i Mamaloi, które Przybyszewski wraz z żoną Jadwigą przyswoił polskim czytelnikom. Refleksja o tym, jak pisarz czytał Ewersa, nie jest przypadkowa, stanowi doskonałą kodę przemyśleń związanych z publicystyką. Autor Śniegu nie tylko tłumaczył wspomniane dzieła, lecz także napisał szkic $\mathrm{Na}$ marginesie tworu Ewersa, który należy czytać jako „wykładnię” jego sztuki.

Zakończenie to jest dość przewrotne, nie stanowi bowiem typowego zwieńczenia prezentowanych wcześniej analiz. Linkner rozjaśnia ciemne plamy biografii pisarza, polemizuje $\mathrm{z}$ obiegowymi sądami, tropi także zagadki (np. Przewodnik po Gdańsku autorstwa księdza Kantaka), generuje nowe tematy, uruchamia konteksty dotyczące np. miejsca fantastyki i psychoanalizy w twórczości Przybyszewskiego. Wszystkie przedstawione w tomie uwagi stanowią cenny materiał dla badaczy, którzy zechcą spotkać się z dziełem Przybyszewskiego i spojrzeć na jego twórczość z innej perspektywy.

Warto jeszcze raz podkreślić, że inspirująca książka Tadeusza Linknera jest również opowieścią o mieście. Gdańsk staje się nowym bohaterem historii polskości.

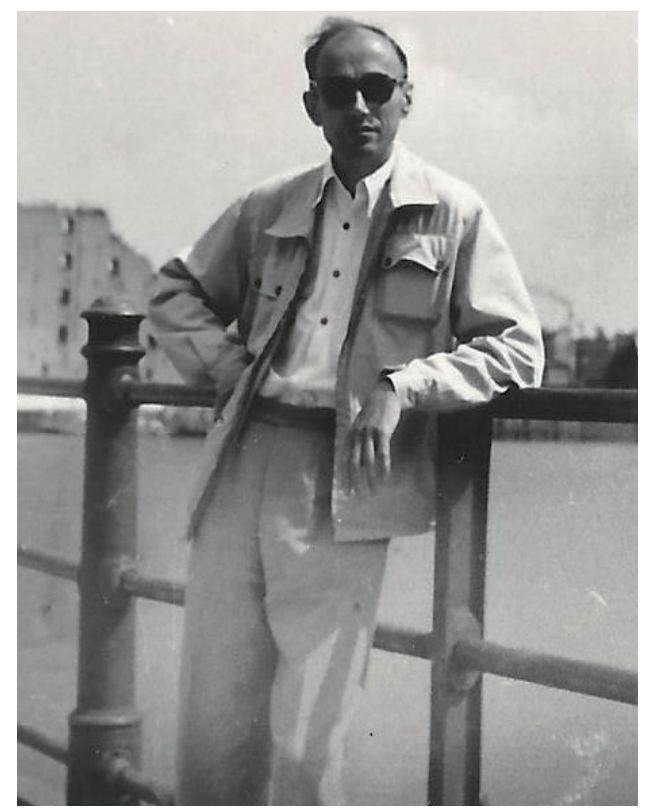

Artur Hutnikiewicz w Gdańsku nad Motławą,

fot. Archiwum prywatne

Hanna Ratuszna - historyk literatury, badacz literatury epoki Młodej Polski, kierownik Zakładu Literatury Młodej Polski i Dwudziestolecia Międzywojennego w Instytucie Literatury Polskiej UMK. E-mail: ikaa@umk.pl. 